\title{
Dinî Motivasyonlu Radikalleşmenin Özellikleri: Nedenler ve Süreç
}

\author{
Characteristics of Religiously Motivated Radicalization: \\ Causes and Process
}

\author{
Gökhan YAŞA *
}

$\ddot{O} z$

Radikalleşme ve radikalleşmenin mahiyeti günümüzde en çok tartışlan konulardan biridir. Çalışmann amacı da din̂े motivasyonlu radikalleşme örüntülerini literatür eksenli açılamakttr. Nedenlerin ve süreçlerin incelenmesi yoluyla radikalleşme örüntülerinin nasıl belirlenebileceği sorusu üzerinde durulmuştur. Özellikle literatüre bakıldiğında radikalleşmenin süreçleri oldukça önemli bir yer kaplamaktadir. Çalısma kapsam olarak temelde radikalleşmeyi tanımlamıs ve radikalleşmenin türlerine yer vermiştir. Bunun yan sıra ise öncelikle çalısmanin ana hedefi olan dinî motivasyonlu radikalleşme üzerinde durulmuştur. Farklı radikalleşme türleri ve süreçleri bulunmasına karşın örüntülerin ortak noktalar taşıdığ görülmektedir. Dinî motivasyonlu radikalleşme kapsamında süreç önemli bir yer kaplamaktadir. Bu kapsamda özellikle üzerinde durulan dinî motivasyonlu radikalleşme süreçleri farkh çalışmalar eksenli olarak irdelenmiştir. Sürecin anlaşılması radikalleşmeye karşı yürütülecek çalışmalar için de önem arz etmektedir.

Anahtar Kelimeler: Radikalleşme, Radikalleşme Süreci, Din̂ิ Motivasyonlu Radikalleşme, Köktencilik, Terörizm.

\section{Abstract}

Radicalization and its nature are one of the most discussed issues today. The aim of the study is to explain the religiously motivated radicalization patterns in terms of literature. The question of how radicalization patterns can be determined through the examination of causes and processes is emphasized. Especially, when the literature

\footnotetext{
* Makale, yazarın “Dinî Referanslı Radikalleşme Örüntüleri: Suriye Örneği” isimli yüksek lisans tezinden üretilmiştir.

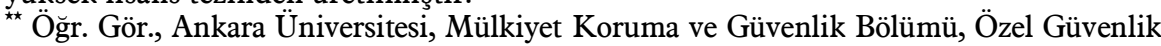
ve Koruma Programı, Ankara, Türkiye, ORCID: 0000-0002-1521-4701, e-posta: agyasa@ankara.edu.tr.
}

Geliş Tarihi / Submitted: 02.03.2021

Kabul Tarihi / Accepted: 02.06.2021 
is examined, it is seen that the processes of radicalization became a subject that has been studied extensively. The scope of the study is to define radicalization and determine the types of radicalization. Primarily, religiously motivated radicalization, which is the main subject of the study, was emphasized. Although there are different types and processes of radicalization, it is seen that the patterns have common points. The process is very important in the context of religiously motivated radicalization. Religiously motivated radicalization processes have been examined in different studies. Understanding the process is also important for studies to be carried out against radicalization.

Keywords: Radicalization, Radicalization Process, Religiously Motivated Radicalization, Fundamentalism, Terrorism.

\section{Giriş}

Radikalleşme tartışmaları son yıllarda artmakla birlikte her zaman önemli bir konu olarak görülmüştür. Radikalizm, ortaya çıkardığ 1 problemlerle birlikte gün geçtikçe hem bireyler hem toplumlar hem de devletler için yüksek bir güvenlik riski oluşturmaya başlamıştır. Bu durum kavramın gittikçe daha popüler olmasına ve tartışılmasına da zemin hazırlamıştır. Radikalleşme hem sosyal alanda hem de güvenlik boyutunda ciddi problemleri meydana getirebilmektedir. Radikalleşme aşamasında gerçekleşen en tehlikeli durumlar inanışın mutlak bir niteliğe bürünmesi, inancın ideolojileştirilmesi, dogmaların ortaya çıkması, biz ve onlar anlayışının yerleşmesi ile dışlama olarak ele alınabilir. $\mathrm{Bu}$ gerçekleşen değişim müsamahasızlığ 1 da beraberinde getirmekte ve sosyal alanda da hoşgörü ve bireyler arasındaki saygı ve anlayış durumunun yok olmasına sebep olmaktadır. Dinî motivasyonlu radikalleşmede fanatik hale gelme durumu iman ile özgürlük düşüncesinin çatışmasına da neden olmaktadır. Fanatik hale gelen birey bunu toplumsal yaşama yansıttı̆̆ında sosyal yaşam içerisindeki karşıt cepheler arasındaki uçurumu daha da açmakta ve kutuplaşmayı hızlandırmaktadır. ${ }^{1}$ Toplumsal birlikteliğin yerini alacak şekilde gelişen dişlama ve buna eşlik eden aşırıcılık sosyal yaşamın ortaklı̆̆ı, birlikteliği ve devamı için büyük tehlike halini almaktadır.

${ }^{1}$ Temel Yeşilyurt, “İslam, İman ve Fundamentalizm”, Kelam Araşttrmaları, 2004, Say1 2-2 s. 92-93. 
Günümüzde aynı zamanda radikalleşme sürecinin önemli evreleri için yüz yüze temas ve örgütsel temas gerekliliği de ortadan kalkmıştır. İletişim devrimi ile birlikte yaşanan değişim ve dönüşüm dijital medyanın ve sosyal medyanın hayatımıza dâhil olmasına sebep olmuştur. Bu açıdan bakıldığında televizyon, gazete, radyo gibi örnekleri verilebilecek olan tek yönlü bir akışa sahip iletişim araçlarının aksine dijital dönüşümün etkisiyle çift taraflı sağlanabilecek bir iletişim olanaklı hale gelmiştir. Söz konusu durum ise dijital veya sosyal medya gibi karşılıklı bir iletişimi kolaylaştırmış, aradaki mesafeyi kısaltmıştır. Sosyal medya sayesinde artık daha geniş bir kitle etkileşiminden söz edilebilmektedir. İnternetin sağladığ imkânla birlikte yükselen sosyal medya ağları günümüzde otorite sarsıcı bir etki gösterebilmektedir. Arap Baharı süreci ve Wall Street’i İsgal Et (Occupy Wall Street) vb. örnekler bize bugün söz konusu kitle hareketlerinin iletişim gücünü göstermektedir. Bu sosyal ağlar çok daha kolay bir şekilde kitle hareketini yaratmakta ve bu birliktelik sonucunda ise bireysel korkuyu alt ederek eyleme geçme aşamasını kolaylaştırmaktadır. Bu kapsamda meydana gelmiş sosyal hareketler öz düşünümsel bir karaktere sahiptir. Sosyal ağların, blogların veya forumların oldukça işlevsel bir hale gelebildiği görülmektedir. ${ }^{2}$

Radikalleşmenin gerçekleştiği yer de önem taşımaktadır. Batıda gerçekleşen göçmen radikalleşmesinde veya cihat sahası olmayan menşei ülke radikalleşmesinde yalnız kurt saldırıları gibi tehdit potansiyelini içerisinde taşıdığı bilinmektedir. Aynı zamanda cihat bölgelerinden evlerine geri dönen cihatçı radikallerinde bir diğer tehdit unsurunu oluşturduğu bilinmektedir. Radikalleşen kişilerin farklı ülkelerde cihat sahasına adım atmaları yabancı terörist savaşçılar olgusunu da doğurmaktadır. Üçüncü ülkelerden başka bir ülkeye savaşmaya gelen kişiler BM'nin aldığ 2178 sayılı kararla yabancı terörist savaşçı olarak kabul edilmektedir. Bu da mücadelenin sürdürülmesi gereken bir anlam olarak ortaya çıkmaktadır. ${ }^{3} \mathrm{Bu}$ anlamda tehdit değerlendirmelerinde önemli bir konuma sahip oldukları görülmekte radikalleşme önleme çalışmalarının da değerini gösterir niteliktedir.

\footnotetext{
${ }^{2}$ Manuel Castells, İletişim Gücü, (Çev. E. Kılıç), İstanbul Bilgi Üniversitesi Yayınları, İstanbul, 2016, s. 23-25.

${ }^{3}$ UTGAM, “Terör Çalıştayı Raporu”, Polis Akademisi Yayınları, 2016, s. 1-19.
} 
Radikalleşme tartışmalarında üstünde durulan ve odak haline getirilen iki önemli başlık bulunmaktadır. Bunlardan ilki radikalleşmeye neyin sebep olduğunu bulmaktır. Diğer başlık ise radikalleşme sürecini tarif etmek ve aşamalarla açıklamaya çalışmaktır. Günümüzde özellikle yaşadığımız coğrafyada önemli güvenlik sorunlarından biri haline gelmiş olması, kapsamlı ve katmanlı bir problem ele alınması gerekliliği, genellikle tek taraflı veya indirgemeci bir yaklaşımla değerlendiriliyor oluşu, literatürde yapılan çalışmaların bu noktaya yoğunlaşması gibi etkenler çalışmada dinî motivasyonlu radikalleşmenin ele alınmasının nedeni olmuştur. Bu makalede de temel olarak kavramsal olarak radikalleşmenin tanımlanmasının ardından dinî motivasyonlu radikalleşmenin nedenleri üzerinde durulmuştur. Daha sonra farklı şekillerde radikalleşme sürecinin nasıl yaşandığ 1 anlaşılmaya çalışılmış, örüntünün belirlenmesi hedeflenmiştir.

\section{Kavramsal Olarak Radikalleşme}

Radikalizm, Büyük Türkçe Sözlük'te köktencilik olarak tanımlanmaktadır. ${ }^{4}$ Yine aynı kavram, Cambridge sözlüğüne bakıldığında "bir kimsenin politik veya din̂̀ inançlarında daha radikal (aşırı) olma eylemi veya süreci" tanımıyla yer almaktadır. ${ }^{5}$ Fundamentalizm kavramının Türk Dil Kurumu tarafından kökten dincilik başlığı altında tanımlandığını ve "kurulu düzenin temellerini din̂̂ kural ve inançlar doğrultusunda değiştirip uygulamadan yana olan tutum veya ögreti, fundamentalizm" olarak açıklandığını görüyoruz. ${ }^{6}$ Radikalizm ve bu kavrama benzer bir şekilde kullanılan fundamentalizm kavramları genel olarak ayrılıkçı veya etnik örgütlerle dinsel temele sahip toplumsal hareketler, aşırı sağ yahut sol ideolojik örgütlenmeleri ele almak için kullanılmaktadır. Radikalizm, toplumsal ve aynı zamanda siyasal boyutta bir değişim ve dönüşümün sağlanması amacıyla salt siyasal araçları kullanmakla kalmayıp bu köklü değişimler için şiddetin de araçsallaştırıldı̆̆ı bir fonksiyona sahiptir. Bu bakımdan şiddetin araçsallaştırılması bir bakıma "devrimci şiddet" olarak da ele alınmaktadır. ${ }^{7}$

\footnotetext{
${ }^{4}$ TDK, "Radikalizm”, Güncel Türkçe Sözlük, https://sozluk.gov.tr adresinden alınmıştır.

${ }^{5}$ Cambridge Dictionary, "Radicalism", dictionary.cambridge.org, https://dictionary. cambridge.org/dictionary/english/radicalization adresinden alınmısttır.

${ }^{6}$ TDK, “Köktendincilik”, Güncel Türkçe Sözlük, https://sozluk.gov.tr adresinden alınmıştır.

${ }^{7}$ Hilmi Demir, Radikal Selefi Hareketler ve Terör Örgütleri Kavram ve Teorik Çerçeve,
} 
Radikal grupların özelliklerinin beş ana başlıkta toplandığ görülmektedir. İlk olarak dikkat edilmesi gereken nokta var olan radikal grupların toplum içerisinde kendi ideolojilerine ve düşünce kalıplarına uygun şekilde birtakım sorunlar ve şikâyetler temelinde ortaya çıkışıdır. İkinci başlıkta ise söz konusu radikal grupların mevcut siyasi, sosyal veya ekonomik durumdan hoşnutsuz olduğu göz önünde bulundurulmaktadır. Bahsi geçen gruplar var olan politik düzende sorunlarını çözememekte, bunlara karş1 cevap bulamamakta ve siyasal mekanizmaların bu amaçla işlemesini sağlayamamaktadırlar. Bu yaşanan durum kurumlara karş1 güveni zayıflatırken aynı zamanda otoritelerin meşruluğunu bahsi geçen bireylerin gözünden tartışmaya açmaktadır. Üçüncü başlıkta ise radikal grupların grup içi dinamiklerini oluşturduğu görülmektedir. Kendi grup içi değerlerini meydana getiren grubun öteki olarak görülen grup dışındakilerle olan ayrımını da arttırdığı vurgulanmaktadır. Bu durum grupların eylemlerini gerçekleştirirken bakış açılarını da anlamak bakımından önemlidir. Dördüncü başlıkta ise radikal grupların sahip olduğu ideolojilerinin şiddet kullanımını meşrulaştırdığı ve kolaylaştırdığı görülmektedir. Meydana getirilen şiddet ise genellikle ilk olarak hoşnutsuzluğu doğuran dış gruba doğru yöneltilmektedir. Bu durum ise özellikle sosyal kimlik teorisinin radikalleşmeye geçiş aşamasında rahatlıkla görülen bir durumdur. Son başlığa baktığımızda ise radikal grupların şiddeti araçsallaştırılmasının var olan hoşnutsuzluklarını gidermede ciddi bir çözüm yolu olarak ortaya çıtı̆̆ı söylenebilir. Grup üyeleri şiddet kullanımının ideolojik başarı için gerekli ve meşru olduğu fikrini kabul etmektedirler bu da benimseme durumu kişileri vicdani iç hesaplaşmalardan korumakta ve gerekli meşruiyeti sağlamaktadır. ${ }^{8}$

Toplumsal kurumlar içerisinde din kurumunun çok önemli bir yeri vardır. Din kurumu, toplumdaki bireylerin hayatında özel bir öneme sahip olmasının yanı sıra kurumun üstlendiği rol bakımından toplum için bütünleştirici bir işleve de sahip görülmektedir. Bununla birlikte bu durumun aksi de mümkün olabilmektedir. Dinî motivasyonun ideolojik

Türkiye Ekonomi Politikaları Araştırma Vakfı, 2016, s. 4-5.

8 Bertsan Doosje, Fathali Moghaddam vd., "Terrorism, Radicalization and Deradicalization”, Current Opinion In Psychology, 2016, 11, s. 80-81. 
fonksiyon bakımından etkili ve kolay bir şekilde araçsal olarak kullanabileceği görülmektedir. ${ }^{9}$ Bu bakımdan çalışmanın ana konusunu oluşturan dinî motifli radikalleşmenin önemli bir çalışma alanı olarak ortaya çıktığı görülmektedir.

Dinî motivasyonlu radikal hareketlerin bir kolektif siyasal şiddet çeşidi olduğu göz önünde bulundurulmalıdır. $\mathrm{Bu}$ anlamda bireylerin sistemin sınırlarını test ettiği veya değiştirmeye çalıştıkları görülmektedir. Amaç, terör eylemlerinde olduğu gibi çeşitli bir şiddet kullanımıyla siyasal gelişmeleri yönlendirebilmek veya etkileyebilmektir. Bu kapsamda gerçekleştirilen eylemler toplumsal kabul gören kodlara, sembollere ve kültür kalıplarına da bir başkaldırı niteliğinde olduğundan bireye de kimlik kazandırma görevini yerine getirdiğine dikkat edilmelidir. ${ }^{10}$ Dinî motivasyonlu radikal hareketlerin eylemlerinin temelinde idealist bir bakış açısının olduğu görülmektedir. Bu durum dinî motivasyonlu radikalleşme bağlamında sadece salt ekonomik yahut siyasi çözümlere odaklanarak dinî alanın çözüm aşamasından dışlanması çözümün de yetersiz kalabileceğini göstermektedir. Aynı zamanda radikalleşen bireyler arasında çok sayıda farklı geçmişe sahip, farklı sosyo-politik sınıflardan gelen insanların olması da bu durumu doğrular bir göstergedir. ${ }^{11}$ Söz konusu durum radikalleşme olgusuna daha sistemli ve kompleks bir yaklaşım geliştirilmesi gerektiğini gösterir niteliktedir.

\subsection{Radikalleşme Türleri}

Bertsan Doosje ve Fathali Moghaddam yapmış oldukları çalışmada radikal grupları türlerine göre beş gruba ayrılmaktadır. ${ }^{12}$ Söz konusu gruplardan ilki milliyetçi veya ayrılıkçı gruplardır. Bu gruplar milliyetçi hedefler peşinde olan, bağımsızlık veya otonomi isteği ile bir ülkeye ait

\footnotetext{
9 Ali Kuyaksil, "Terör Örgütlerinin İdeoloji Unsuru Olarak Kullandığı Bazı Dini Kavramlar", ASSAM Uluslararası Hakemli Dergi, 2014, 1, s. 84-85.

${ }^{10}$ Marella Bodur Ün, Kasım Timur, "Kolektif Siyasal Şiddet Analizine Toplumsal Hareketler Teorisi Yaklaşımı”, Dokuz Eylül Üniversitesi Sosyal Bilimler Enstitüsü Dergisi, 2016, 18-3, s. 525.

${ }^{11}$ Halil Aydınalp, "İntihar Eylemlerinde Dinin Anlamı ve Sınırları", M.Ü. Illahiyat Fakültesi Dergisi, 2009, 37, s. 134.

12 Bertsan Doosje, Fathali Moghaddam vd., "Terrorism, Radicalization and Deradicalization”, Current Opinion In Psychology, 2016, 11, s. 80.
} 
bölgeyi ayırmak isteyen gruplar olabilirler. Bu grupları sınıfladığımızda örnek olarak Türkiye'de PKK Sri Lanka'da Tamil Kaplanları, İspanya'da ETA, İrlanda'da IRA gibi örnekler mevcuttur. Radikalleşme türlerinin ikincisine baktığımızda ise bunu aşırı sağ kanat gruplar olarak adlandırabiliriz. Bu tür gruplar temel olarak göçmenler, mülteciler veya azınlıklar tarafından tehdit edildiği düşünülen "beyaz ırkı" korumak için örgütlenmiş ve zamanla da yükselişe geçen radikal grupları oluşturmaktadır. $\mathrm{Bu}$ gruplara baktığımızda Amerika Birleşik Devletleri'nde Ku Klux Klan veya Almanya'da Pegida Hareketi örnek olabilmektedir. Radikalleşme türlerinin bir diğeri ve üçüncüsü ise aşırı sol kanat gruplardır. Söz konusu hareketler ve gruplar kapitalizmi sorunun ana nedeni olarak görmekte ve adil bir gelir dağılımının yolunun radikallikten geçtiğini düşünürler. $\mathrm{Bu}$ gruplar arasında Kolombiya'da FARC, Almanya'da Kızıl Ordu Fraksiyonu, İtalya'da Kızıl Tugaylar, Türkiye'de Devrimci Halk Kurtuluş PartisiCephesi örnek olarak sayllabilmektedir. Dördüncü grup radikalleşme tipini içeren gruplar olarak ise tek sorunu ele alan, özel amaçlı gruplardır. Söz konusu tek amaçlı gruplar çok geniş bir spektruma odaklanmamakta aksine daha özel ve spesifik hedefleri belirlemektedirler. Radikal çizgide yer almakta olan çevre yahut hayvan haklarına odaklanan gruplar bu kategori çerçevesinde değerlendirilebilmektedir. Söz konusu tip örgüt veya hareketlere örnek olarak ise birçok ülkede faaliyette olan Hayvanların Özgürlügü Cephesi, ABD'de Tanrı'nın Ordusu Grubu (Kürtaj Karşıtlığı) ve Birleşik Krallık’ta Dünya Özgürlüğü Cephesi örnek verilebilmektedir. Tip kategorisinde sonuncu ve beşinci olarak dinî motivasyonlu hareketler ve gruplar yer almaktadır. Söz konusu gruplar dinî önceliklere sahip olup, bu amaçla dinin daha püriten ve katı bir yorumunu sahiplenerek eylemlerini meşrulaştırma çabasına girmektedir. Bunlara örnek olarak ise olarak Libya, Afrika, Irak, Suriye, Afganistan ve dünyanın daha birçok yerinde faaliyette olan DEAŞ, Boko Haram, Hizbullah, Eş Şebab ve El Kaide gibi gruplar örnek verilebilmektedir. ${ }^{13}$ Tablo-l'de ayrımlar daha net görülebilmektedir.

${ }^{13}$ A.ge, s. 80. 
Tablo 1: Radikal grupların tipleri, ana amaçları ve örnekleri ${ }^{14}$

\begin{tabular}{|c|c|c|}
\hline Tipleri & Ana Amaçları & Örnekleri \\
\hline $\begin{array}{l}\text { Milliyetçi veya } \\
\text { Ayrılıkçı } \\
\text { Gruplar }\end{array}$ & $\begin{array}{l}\text { Temsil ettikleri grup için kontrol } \\
\text { ettikleri güvenli bir alan elde etmek }\end{array}$ & $\begin{array}{l}\text { ETA, IRA, PKK, Tamil } \\
\text { Kaplanları }\end{array}$ \\
\hline $\begin{array}{l}\text { Aşırı Sağ Kanat } \\
\text { Gruplar }\end{array}$ & $\begin{array}{l}\text { Özellikle göçmen ve sı̆̆ınmacılara } \\
\text { karşı tepkilerle yükselen ve "beyaz } \\
\text { ırkı" korumayı amaçlayan gruplar }\end{array}$ & Ku Klux Klan, Pegida \\
\hline $\begin{array}{l}\text { Aşırı Sol Kanat } \\
\text { Gruplar }\end{array}$ & $\begin{array}{l}\text { Kapitalizme karşı mücadele ederek } \\
\text { adil gelir dağıtımını savunmak }\end{array}$ & $\begin{array}{l}\text { Devrimci Halk Kurtuluş } \\
\text { Partisi-Cephesi, Kızıl } \\
\text { Tugaylar, Kızıl Ordu } \\
\text { Fraksiyonu, FARC }\end{array}$ \\
\hline $\begin{array}{l}\text { Tek Konuya } \\
\text { Odaklanan } \\
\text { Gruplar }\end{array}$ & $\begin{array}{l}\text { Tek bir spesifik konuya odaklanan } \\
\text { ve mücadele eden gruplar }\end{array}$ & $\begin{array}{l}\text { Dünya Özgürlüğü Cephesi, } \\
\text { Hayvanların Özgürlüğü } \\
\text { Cephesi, Tanrı'nın Ordusu } \\
\text { Grubu }\end{array}$ \\
\hline $\begin{array}{l}\text { Dinî } \\
\text { Motivasyonlu } \\
\text { Gruplar }\end{array}$ & $\begin{array}{l}\text { Dinî önceliklere bağlı olarak dinin } \\
\text { katı bir yorumunu kullanan ve } \\
\text { eylemlerini meşrulaştıran gruplar }\end{array}$ & DEAŞ, El Kaide \\
\hline
\end{tabular}

Radikalleşme farklı motivasyon türlerine göre sınıflandırılabilmektedir. Bu anlamda aşırıcılığın "dinî doktrinlerin yanlış, ve uygunsuz yorumları, bir etnik yapıya yönelik eşit olmayan muamele yapıldığı algısı ve/veya aşırı politik ideolojileri uygulama arzusu” olarak sinıflandırılabildiği görülmektedir. $\mathrm{Bu}$ kapsamda dinî motivasyonlu radikalleşmenin dinî doktrinlerin tahrif edilerek yorumlanmasına dayanan bir istismar faaliyetine dönüştüğü şeklinde yorumlanması mümkündür. Bu durum dinî olgu ve olayların gerçeğinden saptırılarak çarpık versiyonlarının kullanılmasını içermektedir. ${ }^{15}$

\footnotetext{
${ }^{14}$ A.g.e., s. 80 .

15 Andrew Gunn, Ahmet Demirden, "Radikalleşmenin Önlenmesi ve Terörizm Olgusu", Polis Akademisi Yayınlar, 2019, s.12.
} 


\section{Radikalleşmenin Nedenleri}

Radikalleşme olgusu, temel bir ifade ile ideolojik spektrumda aşırı bir konumda bulunma durumunu tarif etmektedir. Buna karşın radikalizmin tek başına terörizm kavramı ile ikame bir şekilde kullanılmasının da yanlış olduğu açıktır. Bununla birlikte şiddeti meşru gören ve şiddete yatkın bir görüşü içerebildiği de açıktır. Burada suç içeren davranışlarla radikal eylemlerin farkına odaklanmak gereklidir. Bu kapsamda radikal bir eylemi veya terör eylemini genel olarak suçtan ayıran noktanın ideolojik öğreti olduğu görülmektedir. İdeoloji; insan doğasının ve bununla birlikte toplumun yahut hayatın nasıl olması ile ilgili olarak birtakım belirli kurallar içeren, sübjektif bir bakış açısına sahip kurallar ve düşünceler dizinini anlatmaktadır. Aynı zamanda ideolojiler farklı alanlardaki düşüncelerin sistemli bir yansıması olabileceği gibi siyaset, ekonomi, toplumsal kurumlar veya toplumsal düzen vb. alanlarda inanç ve önyargıları da içerisinde barındırabilmektedir. ${ }^{16}$ Aşırıcı ideolojiler, temel olarak bir yol haritası sunarak hedefler doğrultusunda hoşgörüden uzak ve şiddete eğilimli bir hale gelebilmekte bu da radikal hale evrilmeyi mümkün hale getirebilmektedir. Bilginin kökenine baktığımızda toplumsal grupların ve sınıfların değer yargıları, sübjektif yaklaşımları, algıları, istekleri ve çıkarları bulunmaktadır. ${ }^{17}$ İdeoloji de buna benzer bir şekilde toplumsal ve siyasal gerçekliğin yorumunu yapmaktadır. İdeolojik idealizme uygun olarak en iyiyi ifade ederek var olan gerçekliği yorumlara görevini de üstlenmektedir. ${ }^{18}$ Terör örgütleri açısından ideoloji ve buna uygun bir doktrinasyon örgütün var olması açısından kilit önemdedir. İdeoloji öncelikli siyasal amaçların belirlenmesi kapsamında da önemli bir rol üstlenmektedir. Radikalleşmenin ayrılıkçı, milliyetçi, dinî, sınıfsal, aşırı sağ veya aşırı sol görüşlerin hepsinde olabileceği düşünüldüğünde politik görüşün isminden çok içeriğinin önemli olduğu ortaya çıkmaktadır.

Çalışma kapsamında ele alınan radikalleşme nedenleri başlıca dinî motivasyonlu radikalleşme için öne sürülen nedenleri kapsamaktadır.

\footnotetext{
${ }^{16}$ Martin Slattery, Sosyolojide Temel Fikirler, Sentez Yayınları, Ankara, 2012, s. 248-249.

${ }^{17}$ Karl Mannheim, İdeoloji ve Ütopya, Nika Yayın, Ankara, 2016.

${ }^{18}$ Birsen H. Örs, "Postmodern Dünyada İdeolojinin Dönüşümü”, İ.Ü. Siyasal Bilgiler Fakültesi Dergisi, 2009, 40, s. 2.
} 
11 Eylül saldırısı sonrasında dünyada başlıca mücadele alanı terörizme kaymış bunun sonucunda da özellikle İslam ülkeleri Batılı ülkelerin bir mücadele alanı haline gelmiştir. Öncelikle Afganistan ile başlayan süreç daha sonra Irak ile devam etmiş günümüzde ise Libya ve Suriye gibi devletleri de içerisine alarak daha büyük bir alana istikrarsızlıklar vasıtasıyla yayılmıştır. Bilindiği gibi çökmüş devlet sistemi, işgaller, istikrarsızlıklar, diş müdahaleler, güvenlik sisteminin yetersizliği gibi etmenler örgütlerin güvenli alan bulabilmesine, kendilerini yapılandırabilmesine ve gelişmelerine olanak tanımaktadır. Bu ülkelerde yaşanan iç ve dış sorunlar ile dış müdahalelerin birleşimi radikalleşmeye daha elverişli bir ortamı da hazırlamaktadır. $\mathrm{Bu}$ durum özellikle bazen yapılan akademik çalışmalarda indirgemeciliğe veya oryantalist düşünceye varabilse de sonuç olarak literatürün bu eksene kaymasına sebebiyet vermektedir. Bu kapsamda yayınlanan literatüre bakıldığında da yerli ya da yabancı çoğu çalışmanın dinî motivasyonlu radikalleşme kapsamında bu ülkelere odaklandığı görülmektedir. Bununla birlikte bu çalışmalar, bu ülkelerde ortaya çıkan ve İslam adına hareket ettiğini iddia eden örgütleri incelemeye almakta bu eksende genel bir şemayı ortaya koymaya çalışmaktadır.

Bireyleri radikal hale getiren veya köktenciliği güçlendiren bireysel veya toplumsal nedenler mevcuttur. Söz konusu bu nedenler Ateş tarafından kısaca "dış etkenler, laikleşme çabaları, toplumsal mekânın değişmesi, meşruiyet ve İsrail faktörü” olarak sıralanmaktadır. Dış etkenler şeklinde tanımlanan madde seküler, batı orjinli veya Hristiyan menşeili fikirler tarafından "istilaya uğramış olan" İslam düşüncesinin ortaya çıkışıdır. Bu durum özellikle kişi üzerinde var olanı ve kutsalları koruma isteğiyle birlikte ortaya çıkmaktadır. Laikleşme çabaları olarak tanımlanan sebep ise Mısır, Türkiye ve İran gibi ülkelerde gerçekleştirilmiş modernleşme hareketlerine ve modernist reformlara oluşan tepkileri ifade etmektedir. Nedenlerden birinin bunun sonucunda bir ters tepki olarak geliştiği düşüncesi bulunmaktadır. Bu gibi ters tepkiler söz konusu ülkelerde modernist reformlarla birlikte açığa çıkmış ve laikliği teşvik edici uygulamalara bir tepki olarak gelişmiştir. Bu karşılaşılan durum dinin tüm hayatı kapsayan bir olgu olduğunu hatırlatmaktadır. Bu şekilde dinin toplumsal alanda da kendini hissettirmesi beklenen bir durumdur. $\mathrm{Bu}$ nedenle toplumda yaşanan gelişmeler kendine direkt olarak karşılık bulabilmektedir. Bunlardan biri de toplumsal mekânın değişmesi ile 
şehirleşmenin hız kazandığı bir değişim içerisinde var olan toplumsal bağların zayıflamanın görülmesi veya çöküşü ile doğrudan ilişkilidir. Söz konusu durum özellikle olumsuz şartlar altında büyüyen genç nesillerde daha büyük bir etkiye sebep olmaktadır. "İşsizlik, evsizlik, siyasal süreçten dışlanmışlık, eğitim ve sağlık gibi sosyal hizmetlerden yoksunluk" gibi sorunlar umutsuzluğu doğurmakta bireyleri de olumsuz yönde etkilemektedir. Aynı zamanda yeni şehirleşmekte olan kırsal bölgelerde veya kırsaldan şehre göçün yaşandığ 1 bölgelerde modern-laik ve geleneksel-dinsel yaşam arasındaki farklılı̆̆ın bireyler üzerinde bir dişavurumu da gerçekleşmektedir. Meşruiyet sorununu incelediğimizde ise genellikle devletlerin siyasal rejimlerinin yaşadığ 1 bir sorun olarak gözükmektedir. $\mathrm{Bu}$ durum yönetimlerin toplumsal adalet, ekonomik kalkınma ve siyasal yozlaşma alanında sergiledikleri kötü performans ile olumsuz bir seyir kazanmakta bunun sonucunda ise meşruiyetlerini olumsuz yönde etkilemektedir. Tarihsel sürece baktığımızda ise Arap devletlerinin 1967 Savaşı'nda İsrail'e yenilmesi gibi nedenlerle de milliyetçi projelerin sekteye uğradığı görülmektedir. Sonucunda ise İslamcı bir görüş önemli bir alternatif olarak ortaya çıkmış ve kendine yer bulmuştur. Yönetimlerin ise bu gelişmelere karşı sergiledikleri tutum süreci daha kötü hale getirmiştir. Muhalif olan unsurlara karşı baskıyı arttıran rejimler daha çok otoriterleşmiş ve söz konusu alternatif muhalif grupların radikalliğe doğru evrilmelerine neden olmuşlardır. İsrail'in kurulmasının çok önemli bir dönüm noktası olduğu da görülmektedir. İsrail'in saldırgan politikası, ABD'den aldığı destek, Filistin sorunu gibi nedenler onu bölgede bir nefret kaynağına dönüştürmüştür. Aynı süreçte Arap devletlerinin İsrail'e karşı verilen savaşları kaybetmesi milliyetçi-modernist rejimlerin gerilemelerine sebebiyet vermiştir. Siyasal anlamda yönetim ve taban arasındaki gerileyen ilişkiler bununla beraber olarak da alternatif siyasal örgütleri yükselişe geçirmiştir. Bugün de geçerli olan bir durum İsrailFilistin meselesinin Müslümanlar arasında ortak bilinç oluşturma açısından önemli bir işlevi üstlenmekte olduğudur. ${ }^{19}$ Küreselleşme sürecinin meydana getirdiği olumsuz sonuçlar da radikalleşmenin nedenlerinden

19 Davut Ateş, “İslam Köktenciliği Kökeni, Genel Nitelikleri, Tanımlar ve Siniflamalar”, Akademik Ortadoğu, 2009, 3-2, s. 67-73. 
olabilmektedir. Bu etkiler öncelikle bölgesel çatışmalar, tarihî travmalar, ülkesel bir dönüşüm gerçekleştirememe, daha adil ve yaşanabilir bir düzenden yoksun olma gibi sıralanabilmektedir. Bununla birlikte gelişmiş ve ilerlemiş görülen Batı seviyesine ulaşamama gibi nedenler de radikal çözümler arama yönünde bireyleri harekete geçirebilmektedir. ${ }^{20}$ Görüldüğü gibi radikalleşmenin nedenlerinin oldukça farklı katmanlara dayalı ve komplike olabileceği görülmektedir.

Horgan, çalışmasında insanların neden terör eylemlerine yöneldiğ sorusuna yanıt aramaktadır. Bu kapsamda öncelikli olarak Batı'da yaşayan genç Müslümanlara odaklanmaktadır. Batıda yaşayan genç Müslüman bireyler hem yabancılaşma duygusunu yaşamakta hem de yerinden edilmişlik hissinin etkileri altında hareket edebilmektedir. Aynı zamanda içerisinde yaşadıkları toplumda aradıkları duygusal bağı ve liderliği de hissedememektedirler. Bahsi geçen durum farklı aidiyet ve liderlik bulma çabası içerisine girmelerine neden olabilmektedir. Bunun başka bir önemli sebebi ise politik çabaların ve siyasal mekanizmaların sağlıklı işlememesi ve demokratik yollar ile gerçekleştirilen protestolar ile bir sonuca ulaşılamayacağına yönelik algıdır. Söz konusu algı insanları daha kolay şekilde şiddetsel yöntemlere yöneltebilmek için bir argüman olarak örgütlerce kullanılmaktadır. İnsanların yaşadıkları deneyim veya yaşananların üzerlerinde yarattığı duygu durumu da önemli bir nedendir. $\mathrm{Bu}$ durumda insanlar kendilerini savaş mağdurlarının yerine koyabilmektedir. Bunların yanı sıra birey kişisel olarak da zorbalıklara maruz kalmış ise bu da etkilidir. Bu nedenle dünyadaki önemli çatışma bölgeleri olarak görülen ve kronik sorun haline gelen İsrail - Filistin sorunu yahut Keşmir problemi ciddi bir radikalleşme potansiyelini içinde ihtiva etmektedir. Yine bireysel olarak devlet görevlilerinden özellikle de asker veya kolluk güçleri gibi resmî görevlilerden görülen ayrımcılık ve zorbalık da insanları radikalliğe iten nedenler arasındadır. Ayrımcılık ve zorbalık gibi bireyin öz saygısına yönelik meydana gelen problemler, bireylerin düşüncesinde devlete ya da sembollerine karşı bir olumsuz bir algıya sahip değilken bile radikalleşmeye zemin hazırlayan sebepler

20 Necmettin Özerkmen, “Terör, Terörizm ve Radikal İslamcı Terör”, Ankara Üniversitesi Dil ve Tarih-Coğrafya Fakültesi Dergisi, 2004, 44-2, s. 258. 
arasındadır. Hatta bu durum önemli bir dönüm noktası olabilmekte ve söz konusu durum bir fikri dönüşüm aşamasının başlangıcı olarak görülebilmektedir. $\mathrm{Bu}$ durum radikal bir harekete katılmak ciddi bir motivasyon aracı haline gelebilmektedir. Radikalleşmekte olan birey toplum karşısında saygı kazandığını düşündüğünde daha geniş bir hareket alanına sahip olmaktadır bu durum bir motivasyon ve ödül olarak görülmektedir. İntihar bombacılarına bakıldığında söz konusu durumun motivasyonla yüksek ölçüde ilintili olduğu görülmektedir. Bunun yanı sıra birey ölümünden sonraki süreç içinde kendinden emin bir görüntü çizmektedir. Bunda özellikle daha önce kendilerini patlatarak istişhâd eylemi düzenlemiş olan kişilerin "şehit" olduğu düşüncesi ve onlara ölümünden sonra gösterilen saygıya da önemli bir husustur. Bu şekilde gerçekleşen ölüm radikalleşen birey için çok daha güzel bir hayata geçiş kapısı olarak da görülmektedir. Radikalleşme nedenleri arasında bir etken olarak radikal bir çevre ile kurulan temasın değişimde önemli bir faktör oluğuna dikkat çekilmektedir. Bahsi geçen radikal çevre bir arkadaş grubu olabileceği gibi daha önce radikalleşmiş akrabalar veya çeşitli sosyal gruplardan da oluşabilir. ${ }^{21}$ Alex Wilner ve Claire-Jehanne Dubouloz ise radikalleşmenin nedenlerini üç ana neden altında toplamaktadır. Bunlar ise sosyo-politik yabancılaşma ve bütünleşme başarısızlığ , dindarlık ve küreselleşme, dış politikalara doğan tepki olarak sıralanabilmektedir. ${ }^{22}$ Lewis ise İslam dünyasının içinde bulunduğu krizi ele alırken özellikle modernleşmenin başarısızlığına ve Suudilerin Vahhabiliği yayma politikalarına dikkat çekmektedir. ${ }^{23}$ Radikalleşmenin bir veya birden çok nedeninin olabileceği görülmektedir. Aynı zamanda nedenlerin bireysel olabileceği gibi sosyal çevre eksenli olabileceği veya yapısal sorunlardan da kaynaklanabileceği hususu önemlidir. Bu anlamda Batı'da göçmen veya göçmen aile kökenli olarak yaşayan bireylerin veya Müslüman ülkelerde yaşayan bireylerin çok farklı nedensel kaynaklara sahip olabileceği de dikkat çekmektedir. Bunlara

${ }^{21}$ John Horgan, "From Profiles To Pathways and Roots to Router Perspectives from Psychology on Radicalization into Terrorism", The ANNALS of the American Academy of Political and Social Science, 2008, 618-1, s. 84-85.

${ }^{22}$ Alex Wilner, Claire-Jehanne Dubouloz, "Homegrown Terrorism and Transformative Learning: An Interdisciplinary Approach to Understanding Radicalization", Canadian Political Science Association Conference, 2009, s. 9-18.

${ }^{23}$ Bernard Lewis, İslam'ın Krizi, Literatür Yayıncılık, İstanbul, 2003. 
karşı önlem alınabilmesi için günlük ve işlevsiz politikalardan çok hem sosyal hem siyasal hayatı etkileyecek yapısal önlemlere ihtiyaç duyulduğu açıktır.

\section{Radikalleşme Süreci}

Radikalleşme süreci altı ana başlık olarak ele alınabilmektedir. Söz konusu altı başlık ise bağlamsal, stratejik, ideolojik nedenler ile bireysel mağduriyetler, radikal topluluklar ile temas ve kitlesel faktörlerdir. İlk olarak bağlamsal başlığın sosyal medya ve sanal propaganda gibi nedenler içerebildiği görünmesine karşın bunun asıl neden haline gelebilmesi için farklı düzeylerde dışlanmaya, baskıya, ekonomik veya siyasal sıkıntılara haiz olması gerekmektedir. Bu da toplumsal birleşimli sorunlarla birlikte etkili olabileceğini göstermektedir. Stratejik nedenlerin kişilerin rasyonel temelli yaklaşımlarında yer aldığı görülmektedir. Şiddete varan bir radikalleşme sadece bir yok etme veya zarar verme isteğinden öte ileriye yönelik olan planın uygulanması şeklinde gelişmektedir. İdeolojik nedenler ise belli bir doktrine bağlı olarak bireyin hayata bakış açısındaki iyi/kötü ve doğru/yanlış kavramlarını şekillendirmesini sağlayan bir filtre fonksiyonunu içermektedir. Bunun yanı sıra İdeoloji eylem sürecinde de önemli bir meşruiyet kaynağını sağlama görevini üstlenmektedir. Yaşanan bireysel mağduriyetler ise söz konusu duruma karşı bir tepki biçiminde oluşmaktadır. Ayrımcılığa veya haksızlığa uğradığını düşünen kişi için bu çok etkili bir neden olabilmektedir. Grupsal sebepler de temel olarak aynı mekânı ve sosyal çevreyi paylaşan bireylerin birbirlerini etkilemesi ve yarattıkları etkiye dayanmaktadır. Bahsi geçen durumlarda bu durum aynı okulu, cezaevini yahut mescidi paylaşmakta olan kişiler arasından çıkabileceği gibi aynı sosyal çevre, ortak arkadaşlar veya aile içerisinde de meydana gelebilmektedir. Kitlesel faktörler de ise daha büyük ölçekli olayların etkili olduğu görülmektedir. Burada bahsi edilen ise bask1 altında tutulma, yasaklar gibi faktörler olabilmektedir. ${ }^{24}$ Clark Mccauley ve Sophia Moskalenko ise yapmış oldukları çalışmada radikalleşme sürecini üç farklı aşama altında ele almıştır. Bu aşamalar bireysel, grupsal ve kitlesel düzeylerde ele alınmaktadır. İlk olarak bireysel düzeyde radikalleşmeyi ele aldığımızda buna neden olan unsurlardan ilkinin kişisel

${ }^{24}$ Hilmi Demir, "Radikalleşme Süreçlerinde İdeoloji ve İtikadi İdeolojinin Rolü Üzerine”, Ortadoğu, 2017, 9-80, s. 11-13. 
mağduriyetler olduğu görülmektedir. Buna örnek olarak Çeçen Kara Dulları örgütü örnek verilebilmektedir. Söz konusu örgüt uğradıkları tecavüz ve kayıplardan ötürü radikal bir yola yönelmişlerdir. Buna benzer şekilde bir diğer mağduriyet söylemi Tamil Kaplanları üyelerinde veya İsrail Ordusu tarafından sürekli baskı altında tutulan Filistin'de intihar bombası eylemi gerçekleştiren örgüt üyelerinde de görülebilmektedir. Söz konusu durum bireysel şekilde zarar görme sonucunda gelişmekte ve intikam alma isteğinin dışa vurumu şeklinde ortaya çıkabilmektedir. Siyasal şikâyetlerin bir sonuca ulaşamaması da bireysel radikalleşmenin bir nedeni olabilmektedir. Bu durum bir politik eğilime, gelişmelere, kararlara tepki gösteren insanların radikalleşmesine örnek olmaktadır. Bu kapsamda değerlendirilebilecek kişilerden biri teknolojik ilerlemelerden endişe duyan ve bu teknolojik gelişmelerden sorumlu tuttuğu kişilere kendi hazırladiğ 1 bombalar gönderen, yüksek ve üst düzey eğitime sahip radikal bir terörist olan “Unabomber” lakaplı Ted Kaczynski'dir. Diğer bir sebebe baktığımızda ise bunun grup içerisinde gerçekleşen radikalleşme olduğunu görmekteyiz. Bireyin risk alarak veya fedakârlıkta bulunarak sempatizanlık düzeyinden aktivistliğe geçişinin bir sonucu olarak ortaya çıkar. Bu sürecin ise adım adım ilerlediği ve belli evrelerle geliştiği aksi birkaç örneğe rağmen söylenebilmektedir. Milgram deneyi de bu bağlamda önemli bir örnektir. Başka bir bireysel radikalleşme süreci ise bir gruba dâhil olmanın sonucu olarak yaşanan radikalleşmedir. Birey, grup ile aile, arkadaş, sevgili gibi yollarla bağlantı kurmaktadır. Bunun radikalleşme süreçlerinde sıkça karş1laşılan nedenlerden biri olduğu görülmektedir. Grup içerisinde ise ortak tehdit ve ortak hedef algısı bütünleşme düzeyini arttırmaktadır. Grup radikalleşmesinde aynı zamanda bir diğer önemli durum ise örgütün içerisinde yer alan yakın görüşlerin de radikal hale gelmesidir. Bu durum "riskli değişim”, "grubun aşırıcıllı̆ı" veya "grubun kutuplaşması" gibi ifadelerle tanımlanmaktadır. Aynı zamanda grup üyelerinde ortaklaşma konusunda da değişiklikler görülmekte ve karşı tarafta yer alan üyeler kendi kutuplarını meydana getirebilmektedir. Başka bir grup radikalleşmesi de izolasyon ve tehdit yoluyla meydana gelen radikalleşmedir. Karşılaşılan bu durum mücadele sürecinde sadece birbirlerine güvenebilecek olan askerî birliklerin ve terörist hücrelerin yapılarıyla benzerlik göstermektedir. Yoğun baskıyla birlikte grup içi uyum ve mutabakat oldukça artmaktadır. Grup dinamiği teorisine baktığımızda ise maddi gerçekliğin değeri ile 
yaratılan sosyal gerçekliğin değerinin birbirinden farklılaştığını görürüz. Maddi gerçekler daha belirgin olmakla birlikte buna karşın sosyal gerçeklik gruba göre belirlenmektedir. Bundan dolayı da "iyi ve kötü nedir? ölmeye değer mi?” gibi sorularla sorgulama sürmektedir. Aynı destek tabanı için mücadele eden ve birbirleriyle rekabette bulunan yapilar grupsal radikalleşmeye neden olabilmektedir. Bu durumda aynı tabanın desteğini kazanmak için mücadele eden örgütler stratejilerini daha da sertleştirebilmekte ve daha radikal olan yollara başvurabilmektedirler. Tersi bir durumda da örgüt fazlaca radikalleşerek ana destek tabanını dâhi kaybetme riskini alabilmektedir. Yürütülen eylemler ile statü arttırmak ve yitirmek arasında küçük farklılıklara bağlı büyük değişimler yaşanabilir. Tabi ki sadece aynı sempatizanlar ve destek tabanı için sürdürülen mücadele radikalleşmeye sebep değildir. Bir diğer nedeni de devlet gücü ile yaşanan rekabettir. Örgüt, zayıf ve yaygın bir halk desteğine sahip olduğunda daha az etki gösterecek ve kısıtlı bazı protesto gösterileri düzenlemeyi tercih edebilir. Bunlar sivil itaatsizlik, destek yürüyüşleri düzenleme gibi nitelikte olabilmektedir. Devletin buna tepkisi ise orantısız olduğunda ve bu ayrım gözetmeksizin insan hakları ihlalleri ve baskılara yol açacak biçimde güç kullanımına dönüştüğünde mevcut güç ilişkilerini etkileyecek bir potansiyele ulaşmaktadır. Yaşanan orantısızlık mağdurlar nezdinde örgüte karşı artan sempati olarak yansıyacak ve zayıf desteğe sahip olan kişileri eyleme yöneltecek itici bir güç olacaktır. Bir diğer nedene baktığımızda ise bunun grup içi rekabet nedeniyle yaşanan radikalleşme olduğunu görürüz. Sosyal karşlaştırma kuramına göre grup içi rekabet yüksek düzeyde olduğunda yoğun çatışma yaratabilme potansiyeline de sahip olmaktadır. Siyasal düşünce içerisindeki farklılıklar bireysel anlaşmazlıklara neden olabilmekte bunlarda grup içi rekabet yoluyla örgütü homojen bir yapı olmaktan uzaklaştırabilmektedir. Bu duruma karşılık ortak hedefler ve ortak motivasyonlar grup birliğini korumaya yardımcı olmaktadır. Grup dışından bir hedef ve tehdit algısının yerleştirilmesi grup içi dinamiği için önem taşımaktadır. Tersi bir durumda ise grup içi rekabet diş rekabete göre çok daha büyük bir potansiyele sahiptir. D1ş kaynaklı tehditlere nazaran içten gelen çatlak sesler veya tehditler çok daha büyük bir tehlike algısı doğurmaktadır. Bu durumun sonucu ise azınlığın gruptan kovulması, iç çatışma ya da fraksiyonlara bölünme şeklinde gerçekleşebilir. Kitle radikalleşmesine verilebilecek ilk örnek dış grup ile gerçekleşen çatışma 
süreci sonucunda kitlesel radikalleşmedir. Kitlesel radikalleşmenin bir başka örneği de "Jujitsu siyaseti" olarak isimlendirilmektedir. Bu durum farklı bir dış grup ile yaşanan çatışma sürecinde gerçekleşen kitlesel radikalleşmedir. $\mathrm{Bu}$ durumda grup dişarıdan tehdit algıladığında veya bir tehdit ortaya çıktığında grup içi uyumun artışı da gözlenmektedir. Bu da grup liderinin saygınlığının artışı, grup içi normların idealleştirilmesi gibi etkiler meydana getirmektedir. Söz konusu etkilere ek olarak vatanseverlik ya da milliyetçilik gibi ön plana çıkabilecek grup içi kimlik örüntüleri de bunu izlemektedir. Jiujitsu siyaseti isimlendirmesinin arka planında düşmanın gücünün başka bir düşmana karşı kullanılması prensibi yatmaktadır. Kitlesel radikalleşme sürecinde farklı ama önemli bir etken ise nefret faktörüdür. Nefret, düşman grubun semboller veya işaretler vasıtasıyla algılanması bununla birlikte karş1 gruba soyut bir kimlik atfetmeyi beraberinde getirmektedir. $\mathrm{Bu}$ karş1 grubu bir insan topluluğu olarak görmekten çıkarmakta ve çatışmaları kolaylaştırmaktadır. Diğer duyguları ve yaklaşımları elimine ederek tamamen düşmanlık temelinde karşı örgüte yaklaşmaya neden olabilmektedir. Bir diğer önemli kitlesel radikalleşme sürecinde etkisi olan kavram ise şehitliktir. Radikal gruplar sıklıkla kayıplarını "şehit" olarak nitelemekte ve üyelerini bu şekilde anmaktadır. Bu durum da grup içi motivasyonu yüksek tutmak için önemlidir. "Şehit" kavramı aynı zamanda örgüte soyut ve önemli bir anlam da kazandırmaktadır. SSehit, davaya adanmışlığın, fedakârlığın ve bu uğurda ölümü göze alabilmenin simgeleşmiş ve vücut bulmuş şekli haline gelmektedir. ${ }^{25}$ Çelik, örgüt üyelerinin militanlaşma sürecini dört aşamada açıklamaktadır. İlk aşama bireyin kimlik bulma ve kimlik arayışında olduğu dönemdir. Söz konusu dönemi ise örgütsel temas takip etmektedir. Ardından gelen süreç ise "örgütsel güdüleme ve güdülenme süreci” olarak tarif edilmektedir. Son olarak görülen süreç ise grup dinamiği bağlamında gelişen örgütte yer alma dönemidir. ${ }^{26}$

25 Clark Mccauley, Sophia Moskalenko, "Mechanisms of Political Radicalization: Pathways Toward Terrorism", Terrorism and Political Violence" Terrorism and Political Violence, 2008, 20-3, s. 418-428.

26 Oktay Çelik, "Dini İstismar Eden Terör Örgütlerinin Radikalleşme Süreci”, Süleyman Demirel Üniversitesi Sosyal Bilimler Enstitüsü Dergisi, 2015, 22, s. 107. 
Tablo 2: Şiddete Giden Yollar: Bireysel, Grup ve Kitle-Toplum Düzeylerinde Politik Radikalleşme Mekanizmaları ${ }^{27}$

\begin{tabular}{|c|c|}
\hline Radikalleşme Düzeyi & Mekanizmalar \\
\hline Bireysel & Kişisel Mağduriyet \\
\hline Bireysel & Siyasi Şikâyet \\
\hline Bireysel & Bir Radikal Gruba Katılarak Radikalleşme \\
\hline Bireysel & Radikal Bir Grup İçerisinde Radikalleşme \\
\hline Grupsal & Grup İçerisinde Radikalleşme -Kutuplaşma- \\
\hline Grupsal & Aşırı İzolasyon ve Tehdit Altında Radikalleşme \\
\hline Grupsal & Aynı Taban İçin Rekabet Sonucu Radikalleşme \\
\hline Grupsal & Grup İçi Rekabet \\
\hline Kitlesel & Jujitsu Siyaseti \\
\hline Kitlesel & Nefret \\
\hline Kitlesel & Şehitlik \\
\hline & \\
\hline
\end{tabular}

Demir radikalleşmenin aşamalarını dörtlü bir süreç şeklinde analiz etmektedir. İlk olarak "toplumsal ayrışma" sürecine odaklanan Demir, bu aşamada radikalleşen bireyin toplumla olan çatışmalarının gün yüzüne çıktığına vurgu yapar. Bu aşamada bireyin bazı değişimler yaşadığı buna bağlı olarak inanç, değer veya kültür yargılarının değiştiği görülmektedir. Söz konusu değişimin toplumun var olan yargıları ile farklılaşmayı ve zıtlaşmayı arttırdığı gözlemlenmektedir. Bu durumun geleneksel toplumlarda yaşanması daha kolaylaşmaktadır. Bunun yanı sıra kurumların politikaları nedeniyle birey toplum dısına itilebilmekte ve toplumsal dışı kalabilmektedir. Tüm bunların dışında bireyin yaşadığı bireysel travmalar da radikalleşme sürecinin başlamasında veya ilerlemesinde etkili olabilmektedir. Birey karşılaştığı sorunlara karşllı kendisini ifade edebileceği bir örgütlenme bulma çabasına girmektedir. Sosyal ve politik sistemde kendisini ifade edilmesi, diyalog kurabilmesi olumlu sonuçlar getirmekte tersi durumda ise

27 Clark Mccauley, Sophia Moskalenko, "Mechanisms of Political Radicalization: Pathways Toward Terrorism", s. 418. 
radikalleşme süreci devam edebilmektedir. Bu yüzden "siyasi radikalleşme" sürecin ise ikinci aşamasını oluşturmaktadır. Bu kapsamda birey siyasette var olan örgütlenmelere dâhil olarak kendi sesini duyurmak veya var olmak isteyebilir. Bunların bireye yeterli gelmemesi durumunda ise sistemi reddeden fakat legal sayılabilecek oluşumlarda kendine yer bulmaktadır. $\mathrm{Bu}$ örgütlenmeler radikalleşme ortamına elverişli sivil toplum görüntüsünde veya STK görünümlü oluşumlar olabileceği gibi dinî mekânlar, kitap evleri yahut dernekler de olabilmektedir. Bu süreçte gerçekleşen sosyalizasyon ile birey yeni bir kimlik arayışını sonuçlandırmakta ve bu yeni edindiği kimliği de aidiyet sağlayarak perçinlemektedir. Bir sonraki aşama ise "itikadi ideolojik radikalleşme" olarak isimlendirilmektedir. Bu aşamada birey yeni sahip olduğu kimliği öğrendiği kavram setleri aracılığıla gerçekleştirebilmektedir. Bu durum kimliğin ifade edilebilmesi için gerekli örgütlenmenin bulunduğu ve "cemaatleşme" sürecinin içine girildikten sonra karşılaşılan evredir. Söz konusu aşamada birey kendini toplumsal ortamdan soyutlamaya başlar ve grupla daha da bütünleşir. Toplumsal bir reddiyenin yaşandığ 1 süreçtir. Birey, dış çevre için "tağut", dönem için "cahiliye", düzenin içindekiler için ise "kâfir, müşrik", tanımlamalarını veya benzerlerini kullanarak kendini ifade edebilir. Bu aşama "Koza dönemi" şeklinde ifade edilebilir. Bir sonraki ve dördüncü aşamada ise "eylemde radikalleşme" adı verilen sürece girilir. Bu süreç iki farklı bir mücadelenin başlangıcıdır. Bu mücadelelerden ilki tebliğ aracılığıyla gerçekleştirilen mücadele iken ikincisi ise cihat mücadelesidir. Tebliğ aracılığıyla grup dışında bulunan insanların bilgilendirilmesi ve gerekirse de yol gösterilmesi amaçlanır. Birey, maddi destek yoluyla da bu mücadeleye dâhil olabilir. Cihat ise mücadelede daha sert olarak nitelendirilebilecek bir aşamasının benimsenmesidir. Bu aşama söz konusu örgütlerin algılayışı bağlamında silahlı mücadelelerden intihar bombacılığına kadar genişletilebilir bir alandır. ${ }^{28}$ Aynı zamanda dinî terimlerin farklı anlamlar yüklenerek ideolojik amaçlara hizmet edecek şekilde kullanılması çok sık rastlanan bir durumdur. Bu hem eylemi meşrulaştırmayı sağlarken hem de topluma karşı propaganda yapılmaktadır. Bu durum aşırıcılığın toplum açısından

\footnotetext{
${ }^{28}$ Hilmi Demir, Radikalleşme Süreçlerinde İdeoloji ve İtikadi İdeolojinin Rolü Üzerine, s. 13.
} 
bölücü rolünü de göstermektedir. ${ }^{29}$ Aynı zamanda cihat düşüncesi eksenli farklı yaklaşımlar da önemlidir. Cihadın ne olduğu, nasıl yapılacağı, önemi ve şehadetle olan ilişkisi sıklıkla örgütler tarafından manipüle edilebilmekte farklı yorumlara neden olabilmektedir. ${ }^{30} \mathrm{Bu}$ gibi durumlar da süreç içerisinde önem kazanmakta ve farklı yorumlamalara neden olabilmektedir.

Alkan ise radikalleşme sürecini yeni bir kimlik inşa süreci olarak beş evrede tasvir etmektedir. Bu süreçte ilk evre ilk temas ile başlamaktadır. Sonraki evrede ise bireyin o süreçte ihtiyaç duyduğu psikolojik, ekonomik veya fizyolojik etmenler kullanılarak kişiyle temas ilerletilmekte yakınlık kurulmaktadır. Diğer takip eden evrede ise örgüt kişiyi çevresinden soyutlayarak daha özel bir alana çekmektedir. Bu alanda kişi daha radikal bir sosyal çevreye sahip olmaktadır. Dördüncü aşama ise çevrenin daha da daralması ve hücre sistematiğinin benimsenmesidir. Bir sonraki ve son evrede ise hücre sistematiğine dâhil olan bireyin algıları, düşünüş biçimi değiştirilmekte, doktrinasyon süreci yaşanmaktadır. Bunun sonucunda ise kişinin bireysel kimliğinin eritilmesi yoluyla tamamen kolektif bir motivasyona sahip olması hedeflenir. ${ }^{31}$

Radikalleşme süreci mikro, mezo ve makro evreler olmak üzere üç aşamalı olarak da ele alınmaktadır. Gerçekleşen birinci evrenin duyarlılık aşaması olduğu görülmektedir. Mikro aşamada bireyin hissettiği statü kaybı, aşağılanma, kişisel başarısızlıklar, suç aktiviteleri veya uyuşturucu bağımlılığı gibi faktörlerin etkili olduğu görülmektedir. Söz konusu durumda statü ve saygı kazanma, kahraman olma ya da kutsal bir amaç uğruna mücadele etme isteği artmaktadır. Mezo düzeyde radikalleşmeye bakıldığındaysa temel olarak sosyal çevreye göre değişmekte olduğu görülmektedir. Bireyin kimliği aile, arkadaşlar veya diğer gruplarda devam eden etkileşimlerle şekillenmektedir. Bireyler özellikle bu aşamada uğradıkları veya uğradıklarını düşündükleri adaletsizliklere ve ayrımcılıklara karşı tavır almaktadırlar. Bu durumda sosyal etkilerin etkisi görülmekte ve bunun insanları savunmasız hale getirebileceğine dikkat edilmelidir. Aşırıcı grupların güçlü bir dinamik

\footnotetext{
${ }^{29}$ Muhammed Faruk Çakır, Ömer Aslan, vd., "Radikalleşme Şiddet İçeren Aşırıcılık ve Terörizm", Polis Akademisi Raporu, 2017, s. 18-19.

${ }^{30}$ Ercan Özyiğit, Radikal İslam'ın Söylemi, Phoenix Yayınları, 2016, Ankara, s. 230-234.

${ }^{31}$ Necati Alkan, El Kaide'den IŞİD'e Din, Şiddet ve Terörizm, Karınca Yayınları, 2016, Ankara, s. 210-213.
} 
grup içi bağ sunduğu bilinmektedir ve bu durum bu durumda bulunan bireyler için bir çözüm olarak gözükebilmektedir. Makro düzeyde radikalleşmeye bakıldığında ise bu durumun büyük toplumsal faktörlerden etkilendiği görülmektedir. Makro düzeyde radikalleşmede küreselleşmenin etkileri ile birlikte Batı hâkimiyetindeki ekonomik, siyasal ve sosyal düzene karşı harekete geçme isteğinin etkili olduğu görülmektedir. Bu kapsamda ikinci evre ise grup üyeliği aşamasıdır. Mikro düzeyde ilk aşamada motive olmuş birey bu evrede gruba olan sadakatini göstermek istemektedir. Kişi kurallara uyduğunda ve grubun değerlerini özümsediğinde grup tarafindan benimsenmektedir. Mezo seviyeye geçildiğinde ise bireyle grup bağlarının güçlendirilmesi gerçekleşmektedir. Bu aşamada kişi eski sosyal çevresinden soyutlanmakta ve grup içi bağlar daha da etkili olmaktadır. Makro düzeye bakıldığında grup etkinliğinin büyük ölçüde arttığı fark edilmektedir. Üçüncü ve son evre ise eyleme geçme aşamasıdır. Birey bu kapsamda mikro düzeyde ilk olarak ölüm fikrine aşina olmaya başlamaktadır. $\mathrm{Bu}$ aşinalık bir arkadaşın olası ölümü olabileceği gibi çatışma sahalarına atılmanın bir sonucu da olabilmektedir. Orta düzeyde gerçekleşen en önemli değişikliğin bireyin kendisini ölüme hazırlayabilmesi olduğu görülmektedir. Bu durumda birey şiddet kullanma aşamasına geçerken ölüm veya yaralanma gibi olası sonuçları da kabullenmeye başlamaktadır. Makro seviyede en önemli farkın şiddet kullanımıyla ilgili olduğu görülmektedir. ${ }^{32}$ Aşağıdaki şemada bu durum gösterilmektedir.

${ }^{32}$ John Horgan, "From Profiles To Pathways and Roots to Router Perspectives from Psychology on Radicalization into Terrorism", s. 81-82. 


\section{Şekil 1: Radikalleşme Süreci ${ }^{33}$}

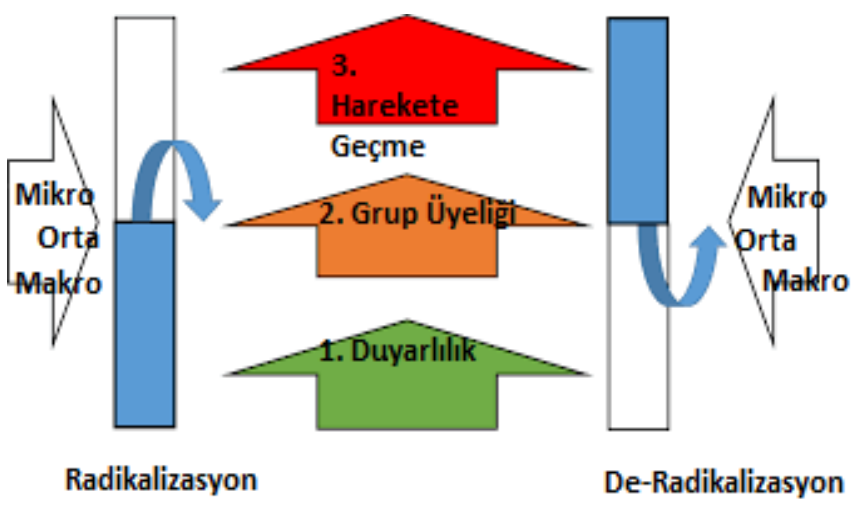

FBI'ın içerisinde yer alan karşı terörizm birimi tarafından tasarlanan radikalleşme süreçleri ön radikalleşme, kimlik edinme, doktrin kazanma ve harekete geçme adı altında dört ana başlıkta sıralanmıştır. İlk olarak süreç bireyin radikalleşme motivasyonunu sağlayan bir nedene bağlı olarak dönüşüm sürecine girmesiyle başlamaktadır. Bu aşamada birey yeni bir arayışa girmekte aynı zamanda da genel bir yeniden yorumlamaya girişmektedir. Süreci başlatan uyaran faktörü kendisi veya başkaları olabileceği gibi iş, okul, camii gibi birçok mekân içinde etkileşimler vasıtasıyla da gerçekleşmiş olabilmektedir. İkinci adım ise bireyin yeni kimliği kabul ettiği aşamadır. Önemli bir değişim ise eski sosyal alışkanlıklarından, yaşamından uzaklaşması ve yeni kimliğine ait bir sosyal ağa dâhil olmasıdır. Üçüncü aşamada ise doktrin kazanma süreci yaşanmaktadır. Doktrinasyon sürecinde birey kendi inancını bir ideolojiye dönüştürmekte ve kendisini güçlü bir şekilde yeni kimliğine bağlamaktadır. Kimliğin oturduğu bir sonraki aşama ise bireyin kendisine bir grup veya örgüt bularak katılım gerçekleştirmesidir. Burada birey kendini üstleneceği dava için eylem gerekliliğine ikna etmektedir. En son aşamada ise birey harekete geçmektedir. Bu aşamada birey artık radikalleşmiş ve

33 Bertsan Doosje, Fathali Moghaddam vd., "Terrorism, Radicalization and Deradicalization", s. 80 . 
yeni bir kimliğe sahip olmuştur. Birey bilinçli bir şekilde, bilerek ve isteyerek radikal eylemlere katılarak terör safhasına geçmeye de hazır hale gelir. Radikalleşen bireyler zaman faktörü değişebilir bir şekilde süreç ilerlerken düşünsel radikallik aşamasından şiddet kullanmaya ve eylem gerçekleştirme aşamasına doğru evrilmektedir. ${ }^{34}$

Tablo 3: Radikallessme Adımlari ${ }^{35}$

\begin{tabular}{|c|c|c|c|}
\hline Ön radikalleşme & Kimlik & Doktrin & Harekete Geçme \\
\hline 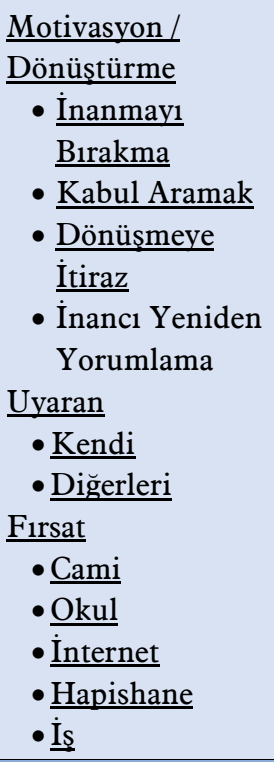 & $\begin{array}{l}\frac{\text { Bireyin sebebi }}{\text { kabul etmesi. }} \\
\text { - Önceki } \\
\text { yaşamdan } \\
\text { kendini izole } \\
\text { etmek } \\
\text { - Yeni bir sosyal } \\
\text { kimliği kabul } \\
\text { etmek } \\
\underline{\text { Temel Bileșenler }} \\
\text { - } \underline{\text { Din Eğitimi }} \\
\text { - } \underline{\text { Basit paramiliter }} \\
\underline{\text { eğitim }}\end{array}$ & $\begin{array}{l}\text { Gruba girmek } \\
\text { - Sosyal } \\
\text { - Terörist } \\
\text { - Sosyal kimliği } \\
\text { güçlendirmek } \\
\text { - Artan güvenlik } \\
\text { araştırması } \\
\text { firsatı } \\
\text { - Eğitim kampı } \\
\text { - Gözlem } \\
\text { aktivitesi } \\
\text { - Finans } \\
\text { Davayı } \\
\text { desteklemek için } \\
\text { eylem gerekliliğine } \\
\text { ikna olma }\end{array}$ & $\begin{array}{l}\text { Bilerek radikal } \\
\text { eylemlere angaje } \\
\text { olma } \\
\text { Operasyonel } \\
\text { aktivitelerin } \\
\text { kolaylaştırıcı işe } \\
\text { alım finansmanı } \\
\text { içermektedir } \\
\text { - Hazırlık } \\
\text { - Planlama } \\
\text { - Infaz }\end{array}$ \\
\hline $\begin{array}{c}\text { IKNA OLMA/ } \\
\text { YENIDEN } \\
\text { YORUMLAMA }\end{array}$ & KABULLENME & TOPLANMA & TERÖRIZZM \\
\hline
\end{tabular}

Radikalleşme sürecinin Batı ülkelerinde yaşandığı durumlarda ekstra etkileri de göz önünde bulundurmak önem kazanmaktadır. Radikaller kimi zaman Fransa, Almanya veya Birleşik Krallık gibi Batı ülkelerinin

${ }^{34}$ FBI Counter Terorism Division, "The Radicalization Process: From Conversion to Jihad”, Federal Bureau of Investigation Intelligence Assesment, 2006.

${ }^{3}$ A.g.e. 
içerisinden de çıkabilmektedir. Söz konusu radikaller arasında burada radikalleşen ve cihat bölgelerine gitmeyen radikaller de yaşamlarını sürdürmektedir. Söz konusu ülkeler sürdürdükleri politikalar ve diğer etkenlerle birlikte zaten örgütler için hedef statüsünde yer almaktadırlar. Bahsi geçen ülkelerde doğan veya yaşayan çoğu göçmen ve göçmen kökenli kişilerin radikalleştikten sonra burada kalmayı tercih etmelerine sebep olmaktadır. Bu kişiler radikalleşmelerinin ardından bir örgütsel temas yaşamasalar bile potansiyel olarak bir tehlike arz etmektedirler. İçerisinde bulunduğumuz dönemde İletişim olanaklarının da gelişmesi ve çeşitlenmesiyle birlikte yalnız kurt (lone wolf) adı verilen saldırıların meydana gelme riskleri de artmaktadır. ${ }^{36} \mathrm{Bu}$ gibi durumlar ve gelişmeler göz önüne alındığında radikalleşmeye karşı ön çalışmalar yapılması ve deradikalizasyon programlarının geliştirilmesi git gide önem kazanmaktadır.

Radikalleşme süreçlerinin tüm bu yaklaşımlar ışı̆̆ında net bir değerlendirilmesi yapıldığında bazı ortak noktalar karşımıza çıkmaktadır. Öncelikle yaklaşımlara bakıldığında kimisinde daha detaylı kimisinde de daha genel bir yaklaşımla sürecin ele alındığı görülmektedir. Buna karşın ilk etap içerisinde en önemli sürecin temas aşaması olduğu söylenebilir. Temas sağlanan yer sürekli etkileşim halinde olmaya olanak veren hapishane gibi yerler olabileceği gibi okul, mahalle gibi süreli etkileşime olanak veren yerler de olabilmektedir. Günümüzde bu kapsamda yaşanan en önemli değişim sanal ortamın da bu sürece dâhil edilmesidir. Sosyal ağlar vasıtasıyla radikal temasın sağlanması oldukça sık karşılaşılan bir durum haline gelmiştir. Daha sonraki ortak aşama ise bir aidiyet hissetme-bağ kurma aşamasıdır. Bu durumda bulunan birey gerek yüz yüze gerekse de çevrimiçi bir yol ile iletişim kursa da bu süreci yaşayabilmektedir. Bu aşama zamansal olarak kişinin arka planına göre farklilık gösterebilecek bir zamansal süreci kapsamaktadır. Aidiyet kuran birey diğer aşamada kendi sosyal çevresinde ve yaşantısında buna göre bir değişim süreci yaşamaktadır. Bu değişim sürecinde aile ve arkadaşlarından tamamen kopabileceği gibi onları da etkileyebilmek niyetiyle bu sosyal ağlarından tamamen de vazgeçmeyebileceği göz önünde bulundurulmalıdır. Git gide daha kapalı bir grup etkileşimiyle yaşamaya

\footnotetext{
${ }^{36}$ Riva Kastoryano, "Radicalization in Europe”, (De)Radicalization and Security, 2017, s. 87-92.
} 
başlayan bireyin değer yargıları da dönüşmekte ve kullandığı dil de dâhil olmak üzere bu yeni değişime ayak uydurabilmektedir. Sürecin sonunda birey adeta bir ideoloji içerisine hapsolmuş konuma düşmekte, kendisini diş dünyadan gelebilecek telkinlere kapatmakta ve olası şiddet eylemlerine katılmaya istekli hale gelebilmektedir.

\section{Sonuç}

Çalışma temel olarak radikalleşmenin neden ve süreçleri konusuna odaklanmıştır. Burada ilk fark edilen radikalleşmenin birçok farklı katmanda ve birçok farklı nedene bağlı olarak meydana gelebileceğidir. Ön radikalleşme aşamasında olan bireyleri fark edebilmek için genel bir nedenler ağına bağlı olarak inceleme yapılabilmesi imkân dâhilinde olsa da bu evrede fark edilebilmesi yine de oldukça zordur. Buna karş1lık radikalleşme süreci incelendiğinde radikalleşen kişilerin daha fazla ortak noktaya sahip olabileceği hususu dikkat edilmesi gereken bir noktadır. Bu kapsamda günümüzde var olan dijitalleşme ve sosyal medya imkânları bireylerin imkânlarını arttırsa da önleme faaliyetleri için her alanın önemli olduğunu bize göstermektedir.

Bireyleri radikal hale getiren nedenlere baktığımızda bunun farklı katmanlarda farklı nedenlere bağlı olarak gerçekleştiğini görebilmekteyiz. Katman olarak bireysel, grupsal veya kitlesel radikalleşme düzeylerinden bahsetmek olasıdır. Nedenler ağına baktığımızda ise çok daha fazla nedenle karşı karşıya olduğumuz açıktır. Buna karşın en çok radikalleşmeyi etkileyen durumlar bireysel mağduriyet, dışlanma, toplumsal bütünleşme başarısızlığı, topluma ait hissetmeme, meşru çerçevede fikirlerini ifade edememe, siyasal mekanizmaya olan inançsızlık, devlet ve kurumlarından görülen ayrımcılık olarak sıralanabilir. Bunlara baktığımızda gerek ön radikalleşme gerek de sonrasında yapılabilecek önleme çalışmaları olmasına karşın en etkili çözümün yapısal düzenlemelerden geçtiği görülmektedir.

Radikalleşme sürecinin nedenlere bağlı olarak gerek sosyal ve ortak mekânlar aracılığıyla gerek dijital medya aracılığıyla gerekse de aile veya arkadaş çevresi aracılığıyla gerçekleşebileceği görülmektedir. Bu sürece baktığımızda ilk olarak toplumla olan farklılıkların veya zıtlıkların ön plana çıktı̆̆ı, fikri bir ayrışma dönemi yaşanmaktadır. Bunu ise temas dönemi izlemektedir; bu aynı zamanda günümüzde dijital ortamda da gerçekleşebilmektedir. Daha sonraki süreçte ise birey örgüte dâhil olma 
aşamasına geçmekte ve örgütsel bütünleşme sağlanmaktadır. Örgütsel bütünleşmenin ardından sosyal çevre değişmekte, örgüte bağlı olarak daralmakta ve doktrinasyon işlemi gerçekleşmektedir. Son aşamada ise birey örgütün tam bir üyesi olarak eyleme geçmeye, fedakârlıkta bulunmaya açı hale gelmektedir. $\mathrm{Bu}$ süreç farklı yerlerde yahut toplumsal mekânlarda gerçekleşiyorsa da aşamalar birbirini takip etmekte ve benzeşmektedir.

Radikalleşmenin toplumsal hayat ve düzen açısından büyük önemi olduğu açıktır. Söz konusu etkiler ilk olarak modern veya gelenekselleşmiş toplum değerlerine yönelmekte ve kendisini hissettirmektedir. Radikalleşebilme olasıllğı yüksek bireylerin sosyal yaşama uyum sağlayamamış yahut kendisini toplumun dışında hisseden insanlar arasından çıkabileceği unutulmamalıdır. Aynı zamanda toplum değerleri bakımından söz konusu grupların hangi aşamada bir tehdit yarattığı, hangi aşamada özgürlük çizgisinin dışına çıktıkları gri bir alan olarak kalmaktadır. Bununla birlikte güvenlik ve toplumsal yaşam açısından radikalleşmenin erken dönemde algilanabilmesi ve kontrol edilmesi gerekmektedir. Aksi durumda ise ilerde ortaya çıkabilecek terör aşamasından önce önlem alabilmek mümkün olmayacaktır. Radikalleşmenin önlenmesi programlarının temel amaçları aşırılığın tırmanışının engellenmesi ve eleman temininin kesilmesidir. Radikalleşme bağlamında dört ana özelliğe yani sorunlar, sıkıntılar, yakınmalar ve ağ tanımlamalarına dikkat edilmesi gereklidir. $\mathrm{Bu}$ özellikler dâhilinde üç ana başlıkta önleme çalışmaları yapılmaktadır. Bunlar; radikalleşme faktörleri, müdahale amacı, faaliyet ve proje türleridir. ${ }^{37} \mathrm{Bu}$ durumun çözülmesi için ilk olarak yapısal problemlerin ön plana çıkarılması gereklidir. Karşı ve akılcı propagandanın öne çıkması, radikallikten uzak olan her türlü fikre yer verilmesi, entegrasyona önem verilmesi, bireylerin dışlanmaması, yurtsuz hissettirmemesi, ayrımcılığa maruz kalmaması gibi önlemler ilk akla gelenlerdir. Yapılması gereken çalışmaların oldukça kapsamlı olduğu görülmekte ve aynı zamanda uzun süreçli bir plan gerektirdiği açıktır. $\mathrm{Bu}$ durum radikalleşenin günümüzdeki en büyük sorunlardan biri haline gelmesinin yanı sıra mücadele etmenin de zorluğunu gösterir niteliktedir.

37 Andrew Gunn, Ahmet Demirden, "Radikalleşmenin Önlenmesi ve Terörizm Olgusu" Polis Akademisi Yaytnlar, 2019, s. 14. 


\section{Summary}

Radicalism or radicalization has become one of the most discussed issues today. Radicalism can be defined as the act or process of being more extreme in one's political or religious beliefs. The first thing to note here is that radicalization can occur at different layers and for different reasons. The study mainly focused on explaining the causes and process of radicalization. It is possible to talk about different types of radicalization. These can be categorized in five different groups, which can be listed as nationalist or separatist groups, extreme right-wing groups, extreme left-wing groups, single-subject groups, and religiously motivated groups.

The causes of radicalization are also important. There are individual or social reasons that make people radical or strengthen fundamentalism. In this context, the study focuses particularly on the processes of religiously motivated radicalization. Especially for this type of radicalization, external factors are listed as secularization efforts, change of social space, legitimacy and Israeli factor. The reason for being defined as external factors is the emergence of Islamic thought "invaded" by ideas of secular, western or Christian origin.

Although the reasons for radicalization vary, the process seems to proceed in a similar way. The radicalization process can be handled under six headings. These are contextual, strategic and ideological reasons, individual victimization, contact with radical communities and mass processes. Clark McCauley and Sophia Moskalenko discussed the radicalization process under three stages. These stages can be observed at individual, group and mass levels. When we first consider radicalization at the individual level, it is seen that the first situation-affecting individuals is personal victimization. This situation leads an expression of the desire to take revenge as a result of individual harm, and the inability to end political grievances may also be a reason for individual radicalization. An example of the radicalization of those who react to a political tendency, events and decisions. Another type of group radicalization is the type of radicalization that occurs through isolation and threat, similar to the structures of military units and terrorist cells that can only rely on each other in war. With the high level of pressures, harmony and consensus within the group increases considerably. Mass radicalization is less common, but a much larger community. In this context, it is seen that 
external factors play a major role along with intra-group conflicts. The reasons for radicalization can be examined more clearly here.

Demir's radicalization is considered a four-stage process. First, the process of "social segregation" takes place. "Political radicalization" is the second stage of the process. The next stage is called "ideological radicalization". The process of "radicalization in action" begins in the fourth stage. The radicalization process is defined by Alkan as the process of creating a new identity in five stages. The first stage in this process starts with the first contact. The next step is to establish a relationship with the new social group. In the third stage, the person moves away from his old social environment. In the fourth stage, the social environment is completely narrowed and consists of like-minded people. In the last stage, the person adopts a new identity. This refers to a completely new person. In addition to these, there are also studies categorizing the process under micro, meso and macro headings. Micro phase refers to individual, meso phase refers to social group and macro phase refers to society.

The study mainly focused on explaining the causes and process of radicalization. It seems that the reasons for radicalization can be quite different. It is also noteworthy that this can happen in different places. However, the process usually proceeds similarly. It is important to understand radicalization, its types, process and causes and pattern as a whole. This will provide important information for de-radicalization studies. It is seen that de-radicalization is of great importance both in the early period and in the rehabilitation period. This is a difficult but effective way to combat radicalization today.

\section{Çatışma Beyanı:}

Araştırmanın yazarn olarak ilgili herhangi bir kurum, kuruluş, kişi ile çıkar çatışması bulunmadiğın beyan ederim.

\section{Destek ve Teşekkür Beyanı:}

Bu çalışmanın hazırlanmasında hiçbir dıs finansmandan yararlanılmamıştr. Çalışma Ankara Yıldırm Beyazıt Üniversitesi Sosyal Bilimler Enstitüsü Sosyoloji Anabilim dalında Prof. Dr. Zafer ÇELIK danısmanlı̆̆nda hazırlanan Öğr. Gör. Abdullah Gökhan YAŞA'ya ait Dinî Referansh Radikalleşme Örüntüleri: 
Suriye Örneği isimli yüksek lisans tezinden üretilmiştir. Çalışmanın gelişmesine ve sonuçlanmasına eşsiz ve önemli katkılar sunan başta danışman hocam olmak üzere tüm hocalarma teşekkür ederim.

\section{Kaynakça}

Kitaplar

ALKAN, Necati; El Kaide'den IŞİD'e Din, Şiddet ve Terörizm, Ankara, Karınca Yayınlar1., 2016.

CASTELLS, Manuel; İletişim Gücü, Çeviren Ebru Kılıç, İstanbul, İstanbul Bilgi Üniversitesi Yayınları, 2016.

ERDEM, Süleyman; Cihatçılar, İstanbul, Yakın Plan Yayınları, 2016.

LEWIS, Bernard; İslam'ın Krizi, Çeviren Abdullah Yllmaz, İstanbul, Literatür Yayınc1lik, 2003.

MANNHEIM, Karl; İdeoloji ve Ütopy,. 1. Baskı, Ankara, Nika Yayın, 2016.

ÖZYİĞİT, Ercan; Radikal İslam'ın Söylemi, Ankara, Phoenix Yayınları, 2016.

SLATTERY, Martin; Sosyolojide Temel Fikirler, 5. Bask1, Düzenleyen: Ümit Tatlıcan ve Gülhan Demiriz, Çeviren Özlem Balkız, Gülhan Demiriz, Hacer Harlak, Cevdet Özdemir, Şebnem Özkan ve Ümit Tatlıcan., Ankara, Sentez Yayıncılık, 2012.

Makaleler

ATEŞ, Davut; "İslam Köktenciliği Kökeni, Genel Nitelikleri, Tanımlar ve Sinıflamalar.” Akademik Ortadoğu, 2009, C. 3 S. 2, s .63-96.

AYDINALP, Halil; "İntihar Eylemlerinde Dinin Anlamı ve Sınırları." M.Ü. İlahiyat Fakültesi Dergisi, 2009, Say1: 37, s. 129-146.

ÇELIK, Oktay; "Dini İstismar Eden Terör Örgütlerinin Radikalleşme Süreci." Süleyman Demirel Üniversitesi Sosyal Bilimler Enstitüsü Dergisi, 2015, Say1: 22, s. 99-122.

DEMIR, Hilmi; Radikal Selefi Hareketler ve Terör Örgütleri Kavram ve Teorik Çerçeve. Değerlendirme Notu, TEPAV, Ankara, Türkiye Ekonomi Politikaları Araştırma Vakfı, 2016, s. 1-8. (Erişim Tarihi: 11.09.2018)

DEMİR, Hilmi; "Radikalleşme Süreçlerinde İdeoloji ve İtikadi İdeolojinin Rolü Üzerine.” Ortadoğu (Ortadoğu Stratejik Araştırmalar Merkezi (ORSAM)) 2017, C. 9, S. 80, s. 11-13.

DOOSJE, Bertsan, Fathali M. MOGHADDAM, Arie W.KRUGLANSKI, Arjan De WOLF, Liesbett MANN, ve Allard R. FEDDES; “Terrorism, Radicalization and Deradicalization." Current Opinion In Psychology, 2016, Sayı: 11, s. 79-84. (Erişim Tarihi: 13.10.2018). doi:10.1016/j.copsyc.2016.06.008.

FBI Counter Terorism Division; (U//FOUO) The Radicalization Process: From Conversion to Fihad. FBI Counter Terorism Division, Federal Bureau of Investigation Intelligence, Federal Bureau of Investigation Intelligence Assesment, 2006, (Erişim Tarihi: 14.10.2018).

GUNN, Andrew, ve Ahmet DEMİRDEN; Radikalleşmenin Önlenmesi ve Terörizm Olgusu. Çalıştay Raporu, Polis Akademisi, Ankara: Polis Akademisi Yayınları, 2019, s. 1-58. 
HORGAN, John; "From Profiles To Pathways and Roots to Router Perspectives from Psychology on Radicalization into Terrorism." The ANNALS of the American Academy of Political and Social Science (SAGE), 2008, Say1: 618 (1), s. 80-94, (Erişim Tarihi: 13.10.2018). doi:10.1177/0002716208317539.

ÜN, Marella Bodur, ve Kasım TİMUR; "Kolektif Siyasal Şiddet Analizine Toplumsal Hareketler Teorisi Yaklaşımı.” Dokuz Eylül Üniversitesi Sosyal Bilimler Enstitüsü Dergisi, 2016, Say1: 18 (3), s. 523-551.

KASTORYANO, Riva; "Radicalization in Europe." (De)Radicalization and Security, 2017, s. 87-92.

KOCADAŞ, Bekir; "Hedefteki Gençlik: Siyasi ve İdeolojik Hareketler Açısından." Uluslararasi İnsan Bilimleri Dergisi, 2004.

KUYAKSİL, Ali; "Terör Örgütlerinin İdeoloji Unsuru Olarak Kullandı̆̆ 1 Bazı Dini Kavramlar." ASSAM Uluslararası Hakemli Dergi (ASSAM - UHAD), 2014, Sayı: 1, s. 79-114.

MCCAULEY, Clark, ve Sophia MOSKALENKO; "Mechanisms of Political Radicalization: Pathways Toward Terrorism", Terrorism and Political Violence." Terrorism and Political Violence (Taylor \& Francis Group, LLC), 2008, C. 20, S. 3, s. 415433.

ÖRS, H. Birsen; “Postmodern Dünyada İdeolojinin Dönüşümü.” İ.Ü. Siyasal Bilgiler Fakültesi Dergisi, 2009, Say1: 40, s. 1-12.

ÖZERKMEN, Necmettin; “Terör, Terörizm ve Radikal İslamcı Terör.” Ankara Üniversitesi Dil ve Tarih-Coğrafya Fakültesi Dergisi, 2004, C. 44, S. 2, s. 247-265.

UTGAM; Terör Çalıstayn Raporu. Terör Çalıştayı Raporu, Uluslararası Terörizm ve Güvenlik Araștırmaları Merkezi (UTGAM), Ankara, Polis Akademisi Yayınları, 2016, s. 1-19.

WILNER, Alex, ve Claire-Jehanne DUBOULOZ; "Homegrown Terrorism and Transformative Learning: An Interdisciplinary Approach to Understanding Radicalization." Canadian Political Science Association Conference, Ottawa: University of Ottawa, 2009, s. 1-26. (Erişim Tarihi: 14.10.2018.)

YEŞILLYURT, Temel; “İslam, İman ve Fundamentalizm.” Kelam Araştırmaları, 2004, C.2, S.2, s. 83-94.

\section{İnternet Kaynakları}

Cambridge Dictionary; Radicalization, https:/dictionary.cambridge.org/dictionary/ english/radicalization. (Erişim Tarihi: Eylül 9.10.2018.)

TDK; Radikalizm, http://www.tdk.gov.tr/index.php?option=com_bts\&arama=kelime \&guid=TDK.GTS.5b962bf05496f2.25993931 (Erişim Tarihi: 9.10.2018.)

TDK; Köktendincilik, http://www.tdk.gov.tr/index.php?option $=$ com_bts\&view $=$ bts\& kategoril $=$ veritbn $\&$ kelimesec $=206716$. $($ Erişim Tarihi: 9.10.2018. $)$ 